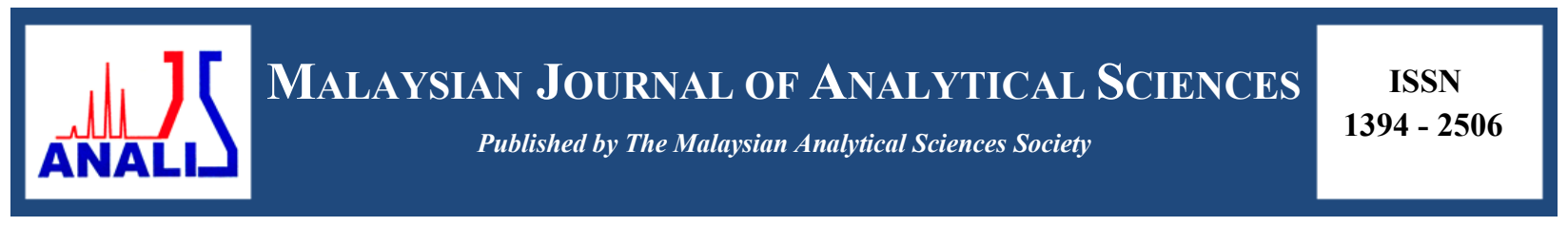

\title{
Alchemilla vulgaris AND Filipendula ulmaria EXTRACTS AS POTENTIAL NATURAL PRESERVATIVES IN BEEF PATTIES
}

\section{(Ekstrak Alchemilla vulgaris dan Filipendula ulmaria Sebagai Pengawet Asli dalam Burger Daging)}

\author{
Khadijah Husna Abd Hamid ${ }^{1}$, Nurul Aini Mohd Azman ${ }^{1}$, Shalyda Sharaani ${ }^{1}$, Norashikin Zain ${ }^{1}$, \\ Normazlinah Ahmad ${ }^{1}$, Ahmad Ziad Sulaiman ${ }^{1}$, Syed Saufi Tuan Chik ${ }^{1}$, Wan Faizal Wan Ishak ${ }^{1}$, \\ Maria Pillar Almajano Pablos ${ }^{2}$ \\ ${ }^{I}$ Chemical and Natural Resources Engineering Faculty, \\ University Malaysia Pahang, Lebuhraya Tun Razak, 26000 Gambang, Pahang, Malaysia \\ ${ }^{2}$ Department of Chemical Engineering, \\ Technical University of Catalonia, Avigunda Diagonal 647, Barcelona 08028, Spain \\ *Corresponding author: ainiazman@ump.edu.my
}

Received: 28 November 2016; Accepted: 5 February 2017

\begin{abstract}
Alchemilla vulgaris (AV) and Filipendula ulmaria (FU) are European medicinal plants possess bioactive compounds that exhibit many pharmacological benefits in human. The present work aims to assess two plants ethanolic extract; AV and FU of their antioxidant activities as natural preservative in beef patties. All plant samples were analysed using total polyphenol content (TPC), their antioxidant activities using Trolox Equivalent Antioxidant Capacity (TEAC), Ferric Reducing Antioxidant Power (FRAP), color and TBARS (Thiobarbituric acid reactive substances) analysis to measure their potential as synthetic preservative in muscle food. The antioxidant activity of FU and AV extracts measured with TEAC were 88.46 and $68.21 \mathrm{mmol}$ of Trolox (TE)/g Dry Weight (DW) respectively. Whereas, FRAP assay were 44.6 and $40.12 \mathrm{mmol}$ of TE/g DW for FU and AV extracts. The effect of lipid oxidation of beef patties were measured with adding $0.1 \%(\mathrm{w} / \mathrm{w})$ of lyophilise FU and AV and Butylated hydroxytoluene (BHT) packed in modified atmosphere (MAP) $\left(80 \% \mathrm{v} / \mathrm{v} \mathrm{O}_{2}\right.$ and $\left.20 \% \mathrm{v} / \mathrm{v} \mathrm{CO}_{2}\right)$ for 14 days storages. FU and AV treated samples showed no significant different compared with BHT ( $\mathrm{p}>0.05)$. Beef patties treated with $0.1 \%$ (w/w) FU showed minimum changes in red color and formation of metmyoglobin throughout storages $(p<0.05)$. These results indicate that these edible plants extract are promising sources of natural antioxidants and can potentially be used as functional preservatives in meat products.
\end{abstract}

Keyword: Alchemilla vulgaris, Filipendula ulmaria, antioxidant, free radicals, polyphenol

\section{Abstrak}

Alchemilla vulgaris (AV) dan Filipendula ulmaria (FU) merupakan tumbuhan perubatan Eropah mempunyai sebatian bioaktif yang boleh memberi kesan positif farmakologi terhadap manusia. Kajian ini bertujuan menganalisa kedua-dua tumbuhan; AV dan FU terhadap aktiviti antioksidan dan sebagai pengawet semula jadi dalam model makanan. Aktiviti antioksidan di dalam FU dan AV ekstrak menggunakan analisis keupayaan antioksidan setara Trolox (TEAC) masing-masing adalah 88.46 dan 68.21 mmol Trolox/g bahan kering. Sebaliknya, aktiviti antioksidan oleh ujian kuasa antioksidan penurunan ferik (FRAP) adalah 44.6 dan $40.12 \mathrm{mmol}$ Trolox/g bahan kering bagi ekstrak FU dan AV. Kesan aktiviti antioksidan disukat dalam burger daging yang mempunyai $0.1 \%(\mathrm{w} / \mathrm{w})$ lyophilise FU dan AV tidak menunjukkan perbezaan yang ketara berbanding dengan $0.1 \%$ BHT apabila disimpan dalam pembungkusan MAP $\left(80 \% \mathrm{O}_{2}\right.$ dan $\left.20 \% \mathrm{CO}_{2} \mathrm{v} / \mathrm{v}\right)$ selama 14 hari $(\mathrm{p}>0.05)$. Burger daging yang dirawat dengan $0.1 \%(\mathrm{w} / \mathrm{w})$ FU menunjukkan perubahan minimum pada warna merah dan pembentukan metmyoglobin sepanjang penyimpanannya $(\mathrm{p}<0.05)$. Keputusan ini menunjukkan bahawa ekstrak tumbuhan yang boleh dimakan ini menjanjikan satu sumber antioksidan semulajadi yang berpotensi untuk digunakan sebagai bahan pengawet di dalam produk daging. 
Kata kunci: Alchemilla vulgaris, Filipendula ulmaria, antioksidan, radikal bebas, polifenol

\section{Introduction}

Over the last decades, the development of ready-to-serve foods products posed new challenges from modern consumer to satisfy and optimized the food cost, appearance and most importantly about the food safety and nutritional values. Moreover, customers recently have been gaining interest in formulation of foodstuff that are healthy and functional, least chemical additives and preferably with natural ingredient [1].Therefore, the food manufacturing industries nowadays are very keen to venture in the variety of healthy food products innovation as new market demand and stimulate purchasing. The use of synthetic antioxidant such as butylated hydroxyanisole (BHA), butylated hydroxytoluene (BHT) and tert-butylhydroquinone (TBHQ) in food formulation developed health concern by public due their possible toxicological effects that may contribute too many diseases [2].

Lipid oxidation occurs in meat product affects the sensory characteristics such as colour, flavour, odour and texture, also causes the loss of nutritional value and the generation of toxic reaction products such as malonaldehyde (MDA) [3]. Alternatively, partial substitution of meat preservatives using natural preservatives had been studied in past years [4 - 8]. Soltanizadeh et al. [9] demonstrated the use of 3\% (w/w) of Aloe Vera improved most quality characteristic that satisfy consumer acceptability. Soya, rosemary, thyme, oregano, broccoli and Gentiana lutea are among healthy substitute in the meat patties role as natural preservatives [10-14]. Hence, it conclude that the natural edible plants responsible to many antioxidant actions may linked to the various type of actives ingredients including polyphenol.

Alchemilla vulgaris (AV) and Filipendula ulmaria (FU) are perennial herbs in the family Rosaceae, widely spread around Europe and Western Asia. They displayed excellent antioxidant activity and many pharmacological benefits in human [15]. AV is well known for their antioxidant activities probably due to the high phenolic contents (rutin, tannins, antocianidins, flavonoids, flavonol, phenolic acid and kempherol) [15 -18]. The plant extract exhibited different pharmacological roles, such as astringent, antidiarrheal, diuretic, depurative, intestinal antiseptic, bacteriostatic and bactericidal, tonic, anti-arthritic and cancer deterrent [19]. Moreover, FU showed relevant biological activity as astringent, antacid, anti-ulcer, anti-rheumatic, immunomodulatory and cytotoxic properties with various polyphenol compositions [15, 20, 21]. Many authors demonstrated the present of numbers of phenolic constituent including derivatives salicylates, flavonols and ellagitannins that contributed to the biological activities in the plant extract $[22,23]$. Moreover, both these plants could act as antioxidants and antimicrobials in food, acting as natural additives that increased food shelf life as well as adding health benefits to potential consumers.

However, the antioxidant activity of AV and FU leaves extract towards lipid oxidation has not been fully determined. Thus, our goals were (1) to quantify the phenolic compounds in AV and FU leaves extract (2) to evaluate the antioxidant activity of $\mathrm{AV}$ and FU leaves extract using in Trolox equivalent antioxidant capacity (TEAC) assays and Ferric Reducing Antioxidant Power (FRAP) (3) to demonstrate the ability of AV and FU leaves extract to inhibit lipid deterioration and their effect toward red color changes in meat patties.

\section{Materials}

\section{Materials and Methods}

Commercial dried AV and FU was kindly supplied by Pàmies Hortícoles (Balaguer, Spain), a registered herbal company. All reagents and solvents used were of analytical grade and obtained from Panreac (Barcelona, Spain) and Sigma Aldrich (Gillingham, England).

\section{Extraction of plants extract}

Dried roots of $\mathrm{AV}$ and FU were finely ground using a standard kitchen food processor. Ground plants were extracted with 50:50 (v/v) ethanol: water in the ratio $1: 10(\mathrm{w} / \mathrm{v})$. The extractions were performed at $60 \pm 1{ }^{\circ} \mathrm{C}$ for 24 hours, in the dark with constant stirring. The plants extract solutions were recovered by filtration using Whatman Filter paper, $0.45 \mu \mathrm{m}$. Part of the supernatant were taken for subsequent use to determine the antioxidant activities. The volume of the remaining supernatant was measured and the excess of ethanol was removed under vacuum using 
a rotary evaporator (Buchi Re111, Switzerland) and kept frozen at $-80^{\circ} \mathrm{C}$ for 24 hours. All extracts were dried in a freeze dryer (Unicryo $\mathrm{MC} 2 \mathrm{~L}-60 \mathrm{~b}^{\circ} \mathrm{C}$, Germany) under vacuum at $-60{ }^{\circ} \mathrm{C}$ for 3 days to remove moisture.

\section{Determination of the total phenolic content}

The Folin-Ciocalteu method was used to determine the total phenolic content (TPC) as reported by Santas et al. [23]. Mixtures of $7.7 \%$ sample, $4 \%$ Folin reagent and $30.8 \%$ of saturated sodium carbonate solution final concentrations were diluted with the sample with 1:25 (v/v). Finally, final mixture was diluted with Milli-Q water, shaken and incubated in the dark for 1 hour. Absorbance at $765 \mathrm{~nm}$ was measured using a microplate reader (Fluostar Omega, BMG Labtech, Ortenberg, Germany) against water as a blank. Gallic acid was used to prepare a standard calibration, and the results were expressed as $\mathrm{mg}$ of Gallic acid equivalents/g dry weight (mg GAE/g DW).

\section{Determination of the Trolox equivalent antioxidant capacity assay}

The antioxidant activities against $\mathrm{ABTS}^{\bullet+}$ radical of plants extract were measured by using a modified TEAC assay, as described by Azman et al. [14]. ABTS ${ }^{\circ+}$ radical cation $(7 \mathrm{mM}$, final concentration) was dissolved before adding potassium sulphate $(2.45 \mathrm{mM}$, final concentration) and allowing the mixture to stand in the dark up to 16 hours. Phosphate Buffer Solution (PBS, $10 \mathrm{mM}$ ) with the $\mathrm{ABTS}^{*+}$ radical cation were incubated at room temperature for 30 minutes before used. Then, the mixture of the $\mathrm{ABTS}^{\circ+}$ radical cation was adjusted to an absorbance of $0.73 \pm 0.2$ $\mathrm{nm}$, using a microplate reader (Fluostar Omega, BMG Labtech, Ortenberg, Germany). The TEAC values for the different concentrations of each compound were interpolated from the Trolox calibration curve and expressed as milligrams of Trolox equivalent per gram of dry weight sample (mg TE/g DW sample).

\section{Determination of the ferric reducing antioxidant power}

The FRAP method was introduced by Benzie et al. [24] and implemented with some modifications. The FRAP solution was prepared in proportions of 10:1:1 of $300 \mathrm{mmol} / \mathrm{L}$ acetate buffer $(\mathrm{pH} 3.6), 10 \mathrm{mmol} / \mathrm{L}, 2,4,6$-tripyridyls-triazine (TPTZ) in $40 \mathrm{mmol} / \mathrm{L}$ hydrochloric acid $(\mathrm{HCl})$ and $20 \mathrm{mmol} / \mathrm{L}$ iron(III) chloride $\left(\mathrm{FeCl}_{3)}\right.$, respectively. FRAP solution was incubated at $37^{\circ} \mathrm{C}$ for 20 minutes before it was mixed with the adequate dilution of the extract. The absorbance was measured at $593 \mathrm{~nm}$ using a microplate reader. Results were compared with the Trolox calibration curve, and concentrations were expressed as micromoles of Trolox equivalents per gram dried weight of sample (mmol of TE/g DW).

\section{Determination of antioxidant activity in food model: Preparation of beef patties}

The lean meat of male cows slaughtered in accordance with approved guidelines of the Animal Ethics Committee was supplied by local market. The meat was collected 7 days after slaughter to allow it to mature and was kept at approximately $-20^{\circ} \mathrm{C}$ for further treatment. Fat and joint tissues from lean meat were trimmed off lean meat (2000 $\mathrm{g}$ ) and the meat was minced through $8 \mathrm{~mm}$ industrial plates. Then, the minced meat was divided into 4 batches $(\mathrm{w} / \mathrm{w})$ and were mixed with $1.5 \%$ of sodium chloride $(\mathrm{NaCl})$ and either i) control (no addition), ii) $0.1 \%$ butylated hydroxytoluene (BHT), iii) $0.1 \%$ FU lyophilise, iv) $0.1 \%$ AV lyophilise. All batches were mixed vigorously for 2 minutes to attain an even distribution of additives throughout the meat. Each sample was moulded into smaller portions (about $20 \mathrm{~g}$ each), stuffed and packed with polystyrene B5-37 (Aerpack) trays and placed in BB4L bags (Cryovac) of low gas permeability $\left(8-12 \mathrm{~cm}^{3} \mathrm{~m}^{-2}\right.$ over 24 hours). The air in the trays was flushed with $80: 20(\mathrm{v} / \mathrm{v})$ oxygen: carbon dioxide $\left(\mathrm{O}_{2}: \mathrm{CO}_{2}\right)$ by EAP20 mixture (Carburos Metalicos, Barcelona) using packaging. Samples were stored in the dark at $4 \pm 2{ }^{\circ} \mathrm{C}$ for 2 weeks to analyse the oxidation for thiobarbituric acid reactive substances (TBARS) method. Every measurement was carried out in triplicate each day.

\section{TBARS assay}

TBARS measurement was used to measure the extent of lipid oxidation over the storage period as described by Grau et al. [25]. The samples $(1 \mathrm{~g})$ were weighed in a tube and mixed with $3 \mathrm{~g} / \mathrm{L}$ aqueous ethylenediaminetetraacetic acid (EDTA) in ratio $1: 1(\mathrm{w} / \mathrm{v})$. Then, the sample was immediately mixed with $5 \mathrm{~mL}$ of thiobarbituric acid reagent using an Ultra-Turrax (IKA, Germany); $32000 \mathrm{rpm}$ speed, for $2 \mathrm{~min}$. All procedures were carried out in the dark and all samples were kept in ice. The mixture was incubated at $97 \pm 1{ }^{\circ} \mathrm{C}$ in hot water for 10 minutes and shaken for 1 minute during the process to form a homogeneous mixture. The liquid sample was recovered by filtration (Whatman Filter paper, $0.45 \mu \mathrm{m}$ ) after the sample was cooled for 10 minutes. The absorbance value for each sample was measured at $531 \mathrm{~nm}$ using a spectrophotometer. The TBARS value was calculated from a 
malonaldehyde (MDA) standard curve prepared with 1,1,3,3 tetraethoxypropane and analysed by linear regression. All results were reported in $\mathrm{mg}$ malonaldehyde per $\mathrm{kg}$ of sample (mg MDA $/ \mathrm{kg}$ sample).

\section{Percentage of metmyoglobin}

The metmyoglobin method was based on the method developed by Xu et al. [26]. An amount $5 \mathrm{~g}$ beef patties were homogenized with $25 \mathrm{~mL}$ of ice-cold $0.04 \mathrm{M}$ phosphate buffer ( $\mathrm{pH}$ 6.8) for 15 second using homogenizer (UltraTurrax, IKA, Germany), which was set at speed setting $2(18000 \mathrm{rpm})$. The homogenate was allowed to stand in 4 ${ }^{\circ} \mathrm{C}$ for 1 hourr and centrifuged at $4500 \mathrm{~g}$ for 20 minutes at $4{ }^{\circ} \mathrm{C}$ using a high-speed freezing centrifuge (GI-20G, Anke, Shanghai, China). The absorbance of the filtered supernatant was read at 572, 565, 545, and $525 \mathrm{~nm}$ with a spectrometer (Fluostar Omega, BMG Labtech, Germany). The percentage of metmyoglobin was determined using the formula; MetMb $(\%)=[-2.514(\mathrm{~A} 572 / \mathrm{A} 525)+0.777(\mathrm{~A} 565 / \mathrm{A} 525)+0.8(\mathrm{~A} 545 / \mathrm{A} 525)+1.098] \times 100$

\section{Statistical analysis}

A one-way analysis of variance (ANOVA) was performed using Minitab 16 software program $(\alpha=0.05)$. The results were presented as mean values $(n \geq 3)$.

\section{Results and Discussion \\ Extraction yield, total polyphenols and antioxidant activity assays}

The European herbs were tested for their polyphenol content and antioxidant ability. Ethanol is used as extraction solvent because is recognized as a GRAS (Generally Recognized as Safe) component that safely used in the food industry application [27]. Rababah et al. [28] reported temperature of $60{ }^{\circ} \mathrm{C}$ found to be the best for extracting phenolic compounds in most common herbs including oregano, thyme and terebinth. In addition, $70 \%(\mathrm{w} / \mathrm{w})$ ethanol extract is used to extract the bioactive compound of AV and FU for acetylcholinesterase and tyrosinase inhibitory assay for treatment of neurodegenerative disorder in human [15].

Table 1 illustrated the extraction yield, phenolic compound and antioxidant activity of AV and $\mathrm{FU}$ in $50 \%$ (w/w) aqueous solvent extract. Generally, AV showed higher yield, phenol content and antioxidant activity than FU extract. The phenolic content value of the AV and FU extracts showed positive correlation to the antioxidant activity value in TEAC and FRAP assays. The total phenolic content of AV and FU extracts allowed the estimation of all phenolic acids, flavonoids, anthocyanin, non-flavonoids and many classes of polyphenol compounds present in the samples. The obtained results are in agreement with Neagu et al. [15] which found phenolic content of AV and $\mathrm{FU}$ are $112.33 \mu \mathrm{g} / \mathrm{mL}$ and $103.00 \mu \mathrm{g} / \mathrm{mL}$ using $70 \%$ ethanol solvent. The authors also identified amount of proanotcyanidins and flavonoes in the plants extract. Previous research finding correlates the total phenolic content with antioxidant activity which may contributes many pharmacological actions in plants extract [23].

Table 1. Extraction yield, TPC and antioxidant activity of AV and FU extracts in ethanol aqueous

\begin{tabular}{lcc}
\hline Activities Plant extract & \multicolumn{2}{c}{ Extraction solvent 50:50 (v/v) EtOH: $\mathbf{H}_{\mathbf{2}} \mathbf{O}$} \\
\cline { 2 - 3 } & $\mathbf{F U}$ & $\mathbf{A V}$ \\
\hline Extraction yield (\%) & $32.1 \pm 0.03$ & $30.4 \pm 0.01$ \\
Total phenolic content (mg GAE/g DW) & $122.11 \pm 0.12$ & $96.43 \pm 0.2$ \\
TEAC (mmol of TE /g DW) & $88.46 \pm 0.83$ & $68.21 \pm 0.33$ \\
FRAP (mmol of TE/g DW) & $44.6 \pm 0.19$ & $40.12 \pm 0.11$ \\
\hline
\end{tabular}

*Mean value $\mathrm{n}=3$ and the standard deviation for each assay is less than 5\%. Gallic Acid Equivalent (GAE), Trolox Equivalent (TE), Dry Weight (DW)

Nevertheless the in-vitro antioxidant activity of TEAC assay gave higher antioxidant activity values of compared to the FRAP assay in both plant extracts. The assay value indicated the extracts potency to scavenge the long-life radical cation ABTS•+ generated in the assay [29]. Research finding from Kiselova et al. [17] showed the antioxidant activity of AV extract in TEAC assay that has strong correlation with the polyphenol content $\left(\mathrm{r}^{2}=0.92\right)$. Moreover, Barros et al. [20] observed FU extract using acetone showed highest value in TEAC assay compare with 
methanol and water. Meanwhile, FRAP assay showed the antioxidant ability of polysaccharides in the plant extracts react with a colorless $\mathrm{Fe}$ (III) to generate a colored $\mathrm{Fe}(\mathrm{II})$-tripyridyltriazine form which can measured at $593 \mathrm{~nm}$ absorbance. A number of in-vitro antioxidant studies has been carried out including TEAC, Oxygen Radical Absorbance Capacity (ORAC) and 2,2-diphenyl-1-picrylhydrazyl (DPPH) radical scavenging shown antioxidant activity potential in the AV and FU extracts [15, 30,31]. However, to the best of our knowledge this is the first report of antioxidant activity extract from AV and FU assessed using FRAP method. Sufficient amount of studies have reported the antioxidant activities of $\mathrm{AV}$ and $\mathrm{FU}$ due to the various polyphenol compositions such as rutin quercetin, synaptic acid and chlorogenic acid. These compounds exert radical scavenging behavior towards free radical mainly reactive radical species (ROS) that could be explain in the FRAP and TEAC value during this study.

\section{Antioxidant activity in food model}

Many strategies on laboratory scale have been developed to improve the stability of shelf life in food models including adding amount of natural extracts that have similar effect as synthetic preservative. The effect of AV and FU on inhibiting lipid oxidation in muscle food has not been described. The oxidation in meat patties was measured in second stage of oxidation, secondary oxidation products (TBARS). In addition the change in color and \% metmyoglobin were measured as physically resemble the freshness of the meat.

\section{TBARS analysis in beef patties}

The study carried out using modified atmosphere packaging for beef patties that was similar to the real packaging in the market. Hence, higher oxygen concentrations in MAP mixtures of $60-80 \% \mathrm{O}_{2}$ and $20-40 \% \mathrm{CO}_{2}$ are commonly used in beef product packaging for retail display in the market. Figure 1 shows lipid oxidation in different burger samples during the 2 weeks of storage. Thiobarbituric acid reactive substances (TBARS) as an indicator of secondary phase of lipid oxidation occurs in the sample are measured based on $\mathrm{mg}$ of malondialdehyde per $\mathrm{kg}$ of the sample. The secondary lipid oxidation is responsible for the alteration of flavor, rancid odor and the undesirable taste in foods [42]. The initial amount of malonaldehyde on day 0 to day 3 varied in the range of $0.1-$ $0.2 \mathrm{mg} / \mathrm{kg}$ of the sample and no significant differences were observed among the burger samples. Starting day 3 onwards control sample showed the highest TBARS value among samples treated antioxidant $(\mathrm{p}>0.05)$. During the 14 days of storage, lipid oxidation proceeded in the control sample and reached $3.90 \mathrm{mg}$ malonaldehyde $/ \mathrm{kg}$ sample.

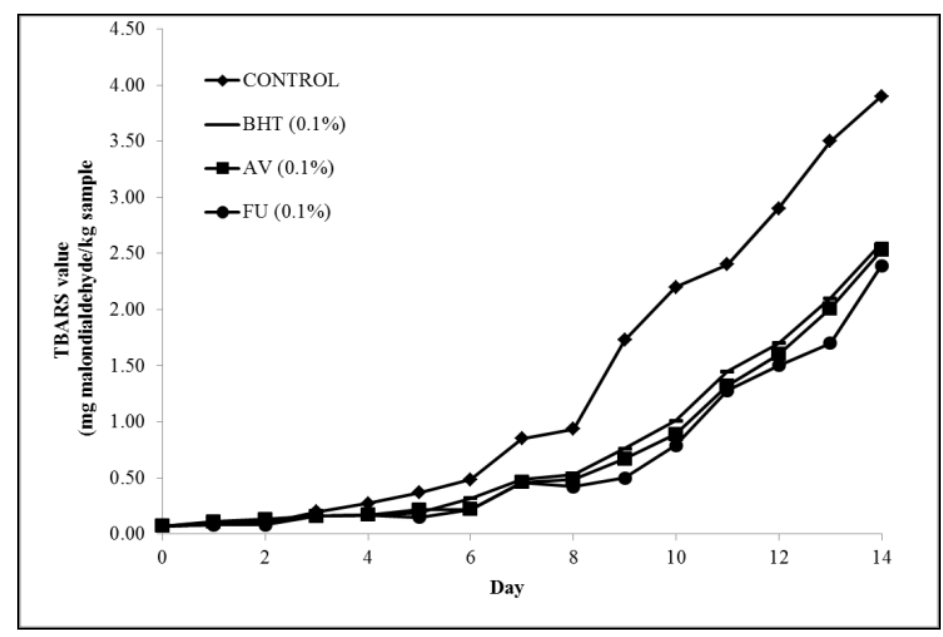

Figure 1. Changes in TBARS values (mg malodialdehyde/kg sample) of control and sample containing different concentrations $(0.1 \% \mathrm{w} / \mathrm{w})$ of $\mathrm{AV}$ and FU extract and BHT extract in MAP atmosphere during 14 days storages at $4 \pm 1{ }^{\circ} \mathrm{C}$ without light. Each sample was measured in triplicate and the average standard deviation for each sample was less than $5 \%$. 
In general, the levels of lipid oxidation in beef patties increased over time and followed the order: $0.5 \% \mathrm{FU}<0.5 \%$ $\mathrm{AV}<0.5 \%$ BHT $<$ Control. The presence of control atmosphere with high oxygen packaging (MAP) resulted in higher TBARS and increased the oxidation rate in muscle food [29, 32, 33]. No statistical difference was observed between sample treated with antioxidant throughout the 14 days storages, however the TBARS value of both samples showed significant difference compared to control samples $(\mathrm{p}<0.05)$. From Figure 1 , the antioxidant potential of AV and FU extract at different storages days showed that the plants have activity equivalent to synthetic antioxidant, BHT $(\mathrm{p}>0.05) .0 .1 \%$ BHT was added as comparison with natural antioxidant beside the FDA guidelines for using BHT is $\geq 200 \mathrm{ppm}$ in meat product [29].

The effect of AV and FU extract on the lipid oxidation in meat has never been reported before. The active properties of $\mathrm{AV}$ and FU attributed to various phenolic acid including flavonols, flavonoids-glucosides, isoflavones, ellagitannins and sinapic acid which prevent propagation of lipid oxidation [15]. The antioxidant activity of phenolic compound is closely related to the hydroxyl group linked to the aromatic ring which is capable donating hydrogen atoms with electrons and neutralizing free radicals. This mechanism blocks further degradation of active oxidizing from such as MDA, which can be measured by TBARS method [34]. The study confirmed the potential of $\mathrm{AV}$ and FU extract to inhibit the lipid degradation in beef patties.

\section{Colour and \% Metmyoglobin}

Figure 2 illustrated the color changes in meat patties were significantly affected by two plant extracts and BHT. The change of meat color is an important factor that impacts visual attraction in consumers. Normally, the colour analysis parameters collected using Minolta Chroma Meter CR-400 represent the lightness (L*), redness (a*), yellowness $\left(\mathrm{b}^{*}\right)$ of the meat surface. However, only a* value are shown in this study due to red color is important color parameter in evaluating meat oxidation. The decrease in redness color makes meat product unacceptable to consumer [35]. In all samples, the a*value decreased as storage time progressed and the red color of control faded very rapidly. The natural color of the plant extract influenced the a*value of the meat at the first 3 days showed significant different from BHT and control $(\mathrm{p}<0.05)$. At the end of storages, the redness value of control sample was significantly lower than the antioxidant treated sample. $0.1 \%$ BHT displayed highest value of a* until 5 days storages and declined gradually onwards $(\mathrm{p}<0.05)$. This finding was expected as BHT role as synthetic antioxidant which used to retain colour and delaying lipid oxidation in the meat. Sample treated with $0.1 \%$ AV exhibited the redness color at the highest value after 14 days storages $(\mathrm{p}<0.05)$, whereas FU sample showed no significant different of a* value with BHT sample. Therefore, the AV and FU at $0.1 \%(w / w)$ extracts as natural preservatives potentially preserved the redness color of the meat and displayed the potentially useful in prolonging the shelf life of the meat product.

Meanwhile Figure 3 presents the effect of natural plants extract and BHT on relative metmyoglobin percentage in beef patties. A significant correlation between metmyoglobin (MetMb) percentage and the redness color features were analysed previously $[29,36]$. The MetMb percentage increased as the storage time increased throughout the 14 days refrigeration, whereas the control showed the highest MetMb value compared to all samples. Initial mean MetMb percentage was $23.9 \pm 0.17$ on 0 day and gradually increase until 7 days with no significant different for all samples $(\mathrm{p}>0.05)$. After 7 days onwards MetMb percentage increased progressively and sample treated with AV exhibited the lowest value significantly at 14 days storages $(\mathrm{p}<0.05)$. FU and BHT samples showed no significant different throughout the storage period, whereas the AV sample showed even superior to such synthetic antioxidant as BHT. According to Kim et al. [33], the MetMb percentage should not exceed 40\%, especially when considering consumer acceptance and AV meat sample was satisfied this limit until day 7. 


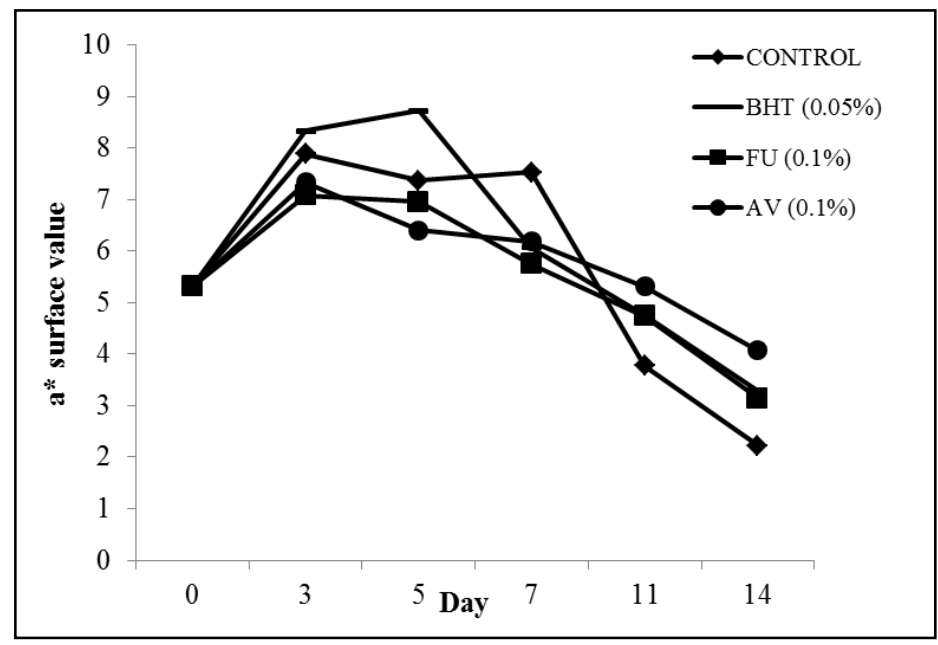

Figure 2. Changes in $a^{*}$ values of control and sample containing different concentrations $(0.1 \% \mathrm{w} / \mathrm{w})$ of $\mathrm{AV}$ and FU extract and BHT extract in MAP atmosphere during 14 days storages at $4 \pm 1{ }^{\circ} \mathrm{C}$ without light. Each sample was measured in triplicate and the average standard deviation for each sample was less than $5 \%$

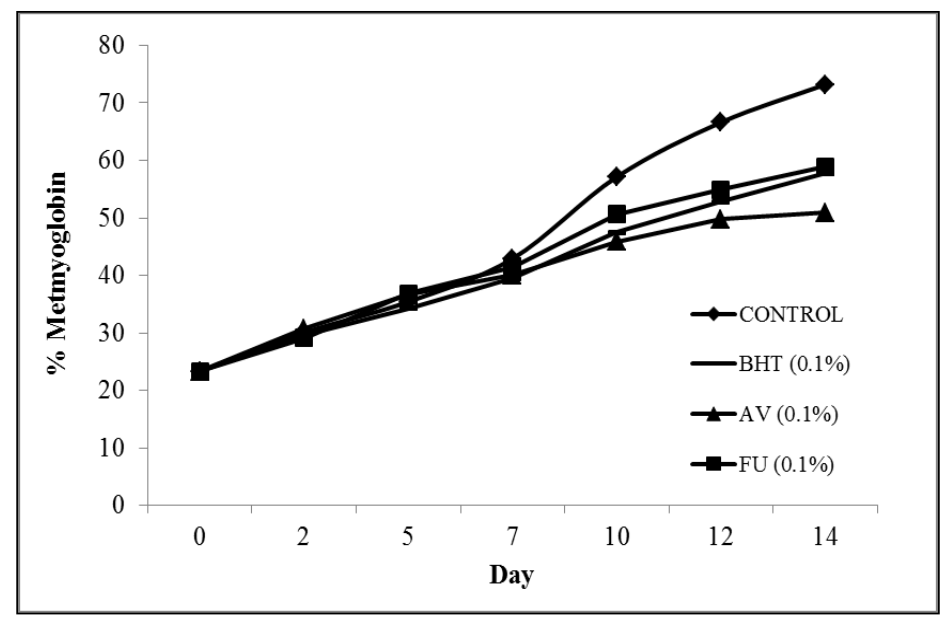

Figure 3. Changes in metmyoglobin percentage of control and sample containing different concentrations $(0.1 \%$ $\mathrm{w} / \mathrm{w}$ ) of $\mathrm{AV}$ and FU extract and BHT extract in MAP atmosphere during 14 days storages at $4 \pm 1^{\circ} \mathrm{C}$ without light. Each sample was measured in triplicate and the average standard deviation for each sample was less than $5 \%$

A number of studies examined the effect of different antioxidant on the meat color and demonstrated the lipid oxidation decrease the redness color of the meat $[8,14,37]$. Xu et al. [26] have proposed that the chemical reaction influences discoloration act as a catalyst of lipid oxidation. Free radicals produced by lipid oxidation in meat are susceptible to initiating the reaction of oxidizing oxymyoglobin (red colour, measured by a*value in Figure 2) to metmyoglobin (brown colour, analysed by relatively formation of metmyoglobin in Figure 3) which results in the discolouration of meat. Hence, the overall changes of \% metmyoglobin were inversely proportional to the value of redness $\left(a^{*}\right)$. The scavenging ability of samples treated with antioxidant can reduce the oxidation of metmyoglobin acting as scavengers of hydroxyl radicals produced from oxidation of oxymyoglobin. The $0.1 \%$ of $\mathrm{FU}$ extract displayed the lowest metmyoglobin percentage and capable to preserve redness color specifically compared to 
synthetic antioxidant, BHT. However, color deterioration and lipid oxidation very dependent on the test system, including the influenced of salt, sample preparation, temperature, oxygen composition, storage time and packaging condition. Thus, modified atmosphere (MAP) at control gas composition of the meat packaging is important to reduce the variable that affect the meat shelf life.

The present study investigates the antioxidant activity potential of two medicinal plants $-\mathrm{AV}$ and $\mathrm{FU}-$ as inhibitor of lipid oxidation in muscle foods, which there is no data in the literature with this regard. The most bio active composition of the plants are the same may due to the same family of Rosaceae, however, the activity values tested are different. Numerous researches founds high content of polyphenol compounds in both FU and AV ethanolic extract, could be explained as antioxidant activity role in preventing lipid deterioration similar as BHT [15,38,39]. The plants contain polyphenol compounds that showed close behavior of antioxidant activity relevant in the study, which are rutin, quercetin, chlorogenic acid and synaptic acid. Rutin and quercetin are responsible exhibit significant pharmacological actives including anti-oxidation, whereas quercetin exert radical scavenging behavior that benefits in many neurodegenerative diseases by mitigating cellular damage induces by radical oxygen species (ROS)[40]. While, Chlorogenic acid (CGA) is a polyphenolic components associate to free radical scavenging and antioxidant activities towards hydrogen peroxide and amyloid beta [41]. The present of synapic acid present has also radical scavenging properties beside the behavior or anti-apotopic and anti-inflammatory [42].

\section{Conclusion}

The aqueous extract of FU and AV plants exhibited different levels of phenolic content and antioxidant activity measured by TEAC and FRAP assays. Therefore, the antioxidant activity of FU and AV extract in the Trolox Equivalent Antioxidant Capacity (TEAC) were 88.46 and $68.21 \mathrm{mmol}$ of TE/g DW respectively while the ferric reducing antioxidant power (FRAP) antioxidant activity for FU and AV extracts were 44.6 and $40.12 \mathrm{mmol}$ of TE/g DW respectively. This study revealed the first time of radical scavenging activity has been evaluated in FU and AV extract using FRAP method. Addition of $0.1 \%(\mathrm{w} / \mathrm{w})$ lyophilise $\mathrm{FU}$ and $\mathrm{AV}$ as an antioxidant in beef patties inhibited lipid oxidation during 14 days of storage in MAP atmosphere at $4 \pm 1{ }^{\circ} \mathrm{C}$ without light. $0.1 \%(\mathrm{w} / \mathrm{w}) \mathrm{FU}$ and AV decreased the discoloration of meat after 14 days of storage $(\mathrm{p}<0.05)$ while FU showed no significant different of color changes in beef patties with BHT (synthetic antioxidant) sample. Thus, this study showed that the $\mathrm{AV}$ and $\mathrm{FU}$ as a potential antioxidant sources for natural preservatives in prolonging the shelf life of the food products.

\section{References}

1. Carocho, M. and Isabel, C. F. R. F. (2013). A review on antioxidants, prooxidants and related controversy: natural and synthetic compounds, screening and analysis methodologies and future perspectives. Food and Chemical Toxicology, 51: $15-25$.

2. Jayathilakan, K., Sharma, G. K., Radhakrishna, K. and Bawa, A. S. (2007). antioxidant potential of synthetic and natural antioxidants and its effect on warmed-over-flavour in different species of meat. Food Chemistry, 105: 908 - 916.

3. Tan, W. and Shelef, L. A. (2002). Effects of sodium chloride and lactates on chemical and microbiological changes in refrigerated and frozen fresh ground pork. Meat Science, 62(1): $27-32$.

4. Triki, M., Herrero, A. M., Jiménez-Colmenero, F. and Ruiz-Capillas, C. (2013). Effect of preformed konjac gels, with and without olive oil, on the technological attributes and storage stability of merguez sausage. Meat Science, 93(3), $351-360$.

5. Salminen, H., Kurt, H. and Jochen, W. (2013). Oil-in-water emulsions as a delivery system for $\mathrm{n}-3$ fatty acids in meat products. Meat Science, 93(3): $659-667.1$

6. Qi, S. and Delong, Z. (2013). Lotus seed epicarp extract as potential antioxidant and anti-obesity additive in chinese cantonese sausage. Meat Science, 93(2): 257 - 262.

7. Moarefian, M., Barzegar, M. and Sattari, M. (2013). Cinnamomum zeylanicum essential oil as a natural antioxidant and antibactrial in cooked sausage. Journal of Food Biochemistry, 37(1): $62-69$.

8. Martín-Sánchez, A. M., Gelmy, C., Estrella, S., José, V., Jamel, B. and José, Á. P. (2013). Date palm byproducts as a new ingredient for the meat industry: Application to pork liver pâté. Meat Science, 93 (4): 880 887. 
9. Soltanizadeh, N. and Hossein, G. (2014). Qualitative improvement of low meat beef burger using aloe vera. Meat Science, 99: 75 - 80.

10. Iturriaga, L., Olabarrieta, I. and Martínez, D. M. I. (2012). Antimicrobial assays of natural extracts and their inhibitory effect against listeria innocua and fish spoilage bacteria, after incorporation into biopolymer edible films. International Journal of Food Microbiology, 158 (1): 58 - 64.

11. McBride, N. T. M., Sean, A. H. and Joe, P. K. (2007). Comparative addition of rosemary extract and additives on sensory and antioxidant properties of retail packaged beef. International Journal of Food Science \& Technology, 42 (10): 1201 - 1207.

12. Campagnol, P. C. B., Dos Santos, B. A., Wagner, R., Terra, N. N. and Pollonio, M. A. R. (2013). The effect of soy fiber addition on the quality of fermented sausages at low - fat content. Journal of Food Quality, 36(1): 41 -50 .

13. Banerjee, R., Verma, A. K., Das, A. K., Rajkumar, V., Shewalkar, A. A. and Narkhede, H. P. (2012). Antioxidant effects of broccoli powder extract in goat meat nuggets. Meat Science, 91(2): $179-184$.

14. Azman, N. A. M., Michael, H. G., Monika, S., Francisco, S. and María, P. A. (2014). Use of lyophilised and powdered Gentiana lutea root in fresh beef patties stored under different atmospheres. Journal of the Science of Food and Agriculture, 95(9): $1804-1811$.

15. Neagu, E., Paun, G., Albu, C. and Radu, G. L. (2015). Assessment of acetylcholinesterase and tyrosinase inhibitory and antioxidant activity of Alchemilla vulgaris and Filipendula ulmaria extracts. Journal of the Taiwan Institute of Chemical Engineers, 52: 1 - 6.

16. Condrat, D., Mosoarca, C., Zamfir, A., Crişan, F., Szabo, M. and Lupea, A. (2010). Qualitative and quantitative analysis of gallic acid in Alchemilla vulgaris, Allium ursinum, Acorus calamus and Solidago virga-aurea by chip-electrospray ionization mass spectrometry and high performance liquid chromatography. Open Chemistry, $8(3): 530-535$.

17. Kiselova, Y., Ivanova, D., Chervenkov, T., Gerova, D., Galunska, B. and Yankova, T. (2006). Correlation between the in vitro antioxidant activity and polyphenol content of aqueous extracts from Bulgarian herbs. Phytotherapy Research, 20(11): 961 - 965.

18. Plotnikov, M. B., Aliev, O. I., Andreeva, V. Y., Vasil'ev, A. S. and Kalinkina, G. I. (2006). Effect of Alchemilla vulgaris extract on the structure and function of erythrocyte membranes during experimental arterial hypertension. Bulletin of Experimental Biology and Medicine, 141(6): 708 - 711.

19. Spiridonov, N. A., Konovalov, D. A. and Arkhipov, V. V. (2005). Cytotoxicity of some Russian ethnomedicinal plants and plant compounds. Phytotherapy Research, 19(5): $428-432$.

20. Barros, L., Alves, C. T., Dueñas, M., Silva, S., Oliveira, R., Carvalho, A. M., Henriques, M., Santos-Buelga, C. and Ferreira, I. C. (2013). Characterization of phenolic compounds in wild medicinal flowers from Portugal by HPLC-DAD-ESI/MS and evaluation of antifungal properties. Industrial Crops and Products, 44: 104 - 110.

21. Blazics, B., Papp, I. and Kéry, Á. (2010). LC-MS qualitative analysis and simultaneous determination of six Filipendula salicylates with two standards. Chromatographia, 71(1): $61-67$.

22. Azman, N. A. M., Sara, P., Lluís, F., Luis, J. and Maria, P. A. (2014). Radical scavenging of white tea and its flavonoid constituents by electron paramagnetic resonance (EPR) spectroscopy. Journal of Agricultural and Food Chemistry, 62(25): 5743 - 5748.

23. Santas, J., Carbo, R., Gordon, M. and Almajano, M. (2008). Comparison of the antioxidant activity of two spanish onion varieties. Food Chemistry, 107(3): 1210 - 1216.

24. Benzie, I. F. and Strain, J. J. (1996). The ferric reducing ability of plasma (FRAP) as a measure of 'antioxidant power': The FRAP assay. Analytical Biochemistry, 239(1): 70 - 76.

25. Grau, A., Guardiola, F., Boatella, J., Barroeta, A. and Codony, R. (2000). Measurement of 2-thiobarbituric acid values in dark chicken meat through derivative spectrophotometry: Influence of various parameters. Journal of Agricultural and Food Chemistry, 48(4): 1155 - 1159.

26. Xu, Z., Tang, M., Li, Y., Liu, F., Li, X. and Dai, R. (2010). Antioxidant properties of Du-zhong (Eucommia ulmoides Oliv.) extracts and their effects on color stability and lipid oxidation of raw pork patties. Journal of Agricultural and Food Chemistry, 58(12): 7289 - 7296.

27. Fernández-Agullóa, A., Pereira, E., Freire, M. S., Valentão, P., Andrade, P. B., González-Álvarez, J. and Pereira, J. A. (2013). Influence of solvent on the antioxidant and antimicrobial properties of walnut (Juglans regia 1.) green husk extracts. Industrial Crops and Products, 42: 126 - 132. 
28. Rababah, T. M., Banat, F., Rababah, A., Ereifej, K. and Yang, W. (2010). Optimization of extraction conditions of total phenolics, antioxidant activities, and anthocyanin of oregano, thyme, terebinth, and pomegranate. Journal of Food Science, 75(7): 626 - 632.

29. Azman, N., Maria, G., Luis, J., Lluis, F. and María, P. A. (2015). The effect of convolvulus arvensis dried extract as a potential antioxidant in food models. Antioxidants, 4: 170-184.

30. Oktyabrsky, O., Vysochina, G., Muzyka, N., Samoilova, Z., Kukushkina, T. and Smirnova, G. (2009). Assessment of anti-oxidant activity of plant extracts using microbial test systems. Journal of Applied Microbiology, 106(4): $1175-1183$.

31. Shilova, I. V., Semenov, A. A., Suslov, N. I., Korotkova, E. I., Vtorushina, A. N. and Belyakova, V. V. (2009). Medicinal plants chemical composition and biological activity of a fraction of meadowsweet extract. Pharmaceutical Chemistry Journal, 43(4): 4 -9.

32. Martínez, L., Djenane, D., Cilla, I., Beltrán, J. A. and Roncalés, P. (2006). Effect of varying oxygen concentrations on the shelf-life of fresh pork sausages packaged in modified atmosphere. Food Chemistry, 94(2): $219-225$.

33. Kim, S. J., Min, S. C., Shin, H. J., Lee, Y. J., Cho, A. R., Kim, S. Y. and Han, J. (2013). Evaluation of the antioxidant activities and nutritional properties of ten edible plant extracts and their application to fresh ground beef. Meat Science, 93(3): $715-722$.

34. Lin, Y., Huang, M., Zhou, G., Zou, Y. and Xu, X. (2011). Prooxidant effects of the combination of green tea extract and sodium nitrite for accelerating lipolysis and lipid oxidation in pepperoni during storage. Journal of Food Science, 76(5): $694-700$.

35. Renerre, M. (2000). Review: biochemical basis of freshmeat color. Proceedings of the $45^{\text {th }}$ International Congress of Meat Science and Technology: pp. $344-352$.

36. Dai, Y., Miao, J., Yuan, S. Z., Liu, Y., Li, X. M. and Dai, R. T. (2013). Colour and sarcoplasmic protein evaluation of pork following water bath and ohmic cooking. Meat Science, 93(4): 898 - 905.

37. Skowyra, M., Falguera, V., Gallego, G., Peiró, S. and Almajano, M. P. (2014). Antioxidant properties of aqueous and ethanolic extracts of tara (Caesalpinia spinosa) pods in vitro and in model food emulsions. Journal of the Science of Food and Agriculture, 94(5): 911 - 918.

38. Rompel, A., Fischer, H., Meiwes, D., Büldt-Karentzopoulos, K., Magrini, A. and Eicken, C. (1999). Substrate specificity of catechol oxidase from lycopus europaeus and characterization of the bioproducts of enzymic caffeic acid oxidation. FEBS Letters, 445: 103 - 110.

39. Momtaz, S., Mapunya, B. M., Houghton, P. J., Edgerly, C., Hussein, A., Naidoo, S. and Lall, N. (2008). Tyrosinase inhibition by extracts and constituents of Sideroxylon inerme L. stem bark, used in South Africa for skin lightening. Journal of Ethnopharmacology, 119(3): 507 - 512.

40. Jiménez-Aliaga, K., Bermejo-Bescós, P., Benedí, J. and Martín-Aragón, S. (2011). Quercetin and rutin exhibit antiamyloidogenic and fibril-disaggregating effects in vitro and potent antioxidant activity in APPswe Cells. Life Science, 89: 939 - 945.

41. Almeida, I. F., Fernandes, E., Lima, J. L., Valentao, P., Andrade, P. B. and Seabra, R. M. (2009). Oxygen and nitrogen reactive species are effectively scavenged by Eucalyptus globulus leaf water extract. Journal of Medicinal Food, 12: 175 - 183.

42. Lee, H. E., Kim, D. H., Park, S. J., Kim, J. M., Lee, Y. W., Jung, J. M., Lee, C. H., Hong, J. G.., Liu, X., Cai, M. and Park, K. J. (2012). Neuroprotective effect of sinapic acid in a mouse model of amyloid $\beta 1-42$ proteininduced alzheimer's disease. Pharmacology Biochemistry and Behaviour, 103: 260 - 266. 